\title{
What was meant by vulgarizing in the Italian Renaissance?
}

\section{Marco Sgarbi}

To cite this article: Marco Sgarbi (2018): What was meant by vulgarizing in the Italian Renaissance?, Intellectual History Review, DOI: 10.1080/17496977.2018.1521628

To link to this article: https://doi.org/10.1080/17496977.2018.1521628

Published online: 06 Dec 2018.

Submit your article to this journal $\llbracket$

View Crossmark data ¿ 


\section{What was meant by vulgarizing in the Italian Renaissance?}

\section{Marco Sgarbi}

Department of Philosophy and Cultural Heritage, Università Ca' Foscari, Venice, Italy

\begin{abstract}
What did it mean to "vulgarize" in Renaissance Italy? Was it simply a matter of translating into the vernacular, or did it mean making a text more accessible to the people - to in some sense popularize it? The answer is far from simple and certainly never one-sided; therefore, each individual case needs to be independently assessed on its own merits. This article seeks to shed some light at least on the major treatments of the theory of vulgarization by the likes of Ludovico Castelvetro, Faustus Longianus, Francesco Robortello, Alessandro Piccolomini, Orazio Toscanella and Girolamo Catena, which were central to the debate from the 1540 s onwards.
\end{abstract}

\section{KEYWORDS}

vulgarization; Ludovico

Castelvetro; Faustus

Longianus; Alessandro

Piccolomini; Orazio

Toscanella; Girolamo Catena

\section{Introduction: translation, tradition and betrayal}

What did it mean to "vulgarize [volgarizzare]" in Renaissance Italy? Was it simply a matter of translating into the vernacular, ${ }^{1}$ or did it mean making a text more accessible to the people ${ }^{2}-$ to in some sense popularize it? $?^{3}$ The answer is far from simple and certainly never one-sided; therefore, each individual case needs to be independently assessed on its own merits.

Transposing from one language to another and making content more accessible are two practices which are not always easy to distinguish between. The two meanings have long coexisted, and their polysemy is just as appreciable today as it was in the Renaissance. What is interesting is that in this period intellectuals began to reflect on the process of vulgarization itself.

In the Italian Renaissance almost any attempt to make content more accessible to a wider public implied at least some form of translation from the classical languages into the vernacular (when the production was not original), and this is what was meant by rendering into the vernacular. With that said, however, we can make no general assumption at least on the basis of the cases we have knowledge of - to the effect that every translation was an instance of popularization. Either way, it is well to remember, as George Steiner points out, that translation is never a simple and neutral transmission of a text from one language to another; it is not a mere linguistic question, because it always produces new knowledge. ${ }^{4}$ Hence, even when translation is not intended as popularization, by making the text or its content more widely known - and also when a radical transformation of both is involved - it nevertheless fulfills the function of generating new 
knowledge. ${ }^{5}$ It is equally certain that to render a classical text into a vernacular language greatly increases the number of its public. ${ }^{6}$

To date, studies focusing on the vulgarization process have for the most part been concerned with the early phases of the Romance languages between the twelfth and fourteenth centuries. ${ }^{7}$ Another line of inquiry focuses on the problem of translation from Greek to Latin during Humanism, ${ }^{8}$ another still on specific geographical areas, for instance France. ${ }^{9}$ However, almost nothing has been written on the theory of vulgarization from classical languages to the vernacular in the Italian Renaissance. ${ }^{10}$ In the rare event that some effort has been made in this direction, scholars have been concerned primarily with the translation of literary texts rather than philosophical and scientific texts. ${ }^{11}$ Only in recent years has there been a surge of interest in the various translation practices that were adopted. ${ }^{12}$ So far, however, nothing systematic has come of it.

Yet there is one very good reason for studying this complex process: the Renaissance, the Cinquecento in particular, was a time of intense blossoming of what we today call vulgarization in all fields of knowledge, especially in terms of prose. ${ }^{13}$ In order to fully grasp the meaning of vulgarization in the Italian Renaissance, it is therefore necessary to examine some of the first-hand accounts rather than focusing exclusively on a-posteriori reconstructions, which inevitably risk distorting reality through the lens of a modern way of looking at things. Even the classification of vulgarization as a literary genre was late in emerging. Few Renaissance intellectuals defined their works as vulgarizations. The word "volgarizzamento" only came into widespread use in the second half of the Seicento, and it was not until the late Settecento and the Ottocento that this category of literary genre really took root, albeit in a non-defined kind of way.

This article therefore seeks to shed some light at least on the major treatments of the theory of vulgarization by the likes of Ludovico Castelvetro, Faustus Longianus, Francesco Robortello, Alessandro Piccolomini, Orazio Toscanella and Girolamo Catena, which were central to the debate from the 1540s onwards. The role played by these authors is particularly significant, as most of them worked on the translation and vulgarization of philosophical and scientific texts, which in part present a different set of challenges from that of purely literary and poetic works. Although making content more understandable is hardly a concern in the case of the latter, such works do raise the problem of metrical correspondence, which is absent in prose works. Even so, as we shall see, the question of preserving certain linguistic forms in the transfer from one language to another persists.

Our reconstruction omits the question of the genres of these texts as something which is correlated but not immediately dependent. Obviously the choice of one literary genre over another implies a different approach to the original text. As Alessio Cotugno has so brilliantly shown, it is difficult to speak of vulgarization without reference to the manner in which a text is vulgarized - in other words, the techniques of exegesis and interpretation that are employed. ${ }^{14}$ Nonetheless, a useful distinction may still be drawn between the quid facti of vulgarization, or how it is produced, and the quid iuris, namely the possibilities and limitations of vulgarization. This present inquiry focuses on the quid iuris, or the theory of the translation.

At its height, when the vernacular had established itself as a language of culture, vulgarization was no longer questioned in terms of its feasibility. ${ }^{15}$ Vulgarization had long since ceased to be the object of criticism, and indeed intellectuals such as Faustus Longianus and Orazio Toscanella came to view the question of its validity as simply superfluous, even 
nonsensical. By then, vulgarization had become a well-established practice. ${ }^{16}$ The problem of developing a theory of translation and vulgarization emerged only later, however, when the vernacular no longer needed legitimizing as a language of culture and the notion that vulgarizing was "extremely beneficial and honorable"17 was becoming widely accepted. It was only when vulgarizations were being printed that serious reflection on a theory of translation and vulgarization began to emerge.

The most pressing concern at this stage was therefore to define the criteria and principles according to which it was possible or even necessary to vulgarize. ${ }^{18}$ Such principles, the quid iuris, were what made it possible to select the best vulgarization technique. This theory of vulgarization - which to start with, at least, turned primarily on the fundamental principles of translation - became possible only when the idea that it was necessary to reproduce the high-register forms of Latin also in the vernacular was abandoned. ${ }^{19}$

Historians have generally tended to reduce the theory of Renaissance translation to a single overarching dichotomy: "do we translate according to the words or the meaning?" 20 This dichotomy has often been associated with a juxtaposition between those who are interested primarily in form, or words, and those who prefer to focus on content, or meaning. The first group usually includes Ludovico Castelvetro, Sebastianus Faustus Longianus, Orazio Toscanella and Girolamo Catena. The assumption is that to vulgarize, for these intellectuals, meant to translate in the strictest sense, in other words to "convert [convertere]", "transpose [transferre]", "interpret [interpretari]" and "render [reddere] or return". It was therefore for the most part a word-for-word translation (verbum pro verbo), against Leonardo Bruni's suggestion. ${ }^{21}$ By contrast, Francesco Robortello and Alessandro Piccolomini, along with many other intellectuals who were concerned not so directly with the theory of translation but with actual translations or the theory of language, for instance Sperone Speroni, Benedetto Varchi, Ludovico Dolce and Claudio Tolomei, were more alive to content. ${ }^{22}$ For them, to vulgarize was not merely to translate, or a word-for-word transposition, but above all a rendering of the true sense of the author's message, in line with Saint Jerome's dictum "do not render word-for-word, but express the original sense [non verbum e verbo, sed sensum exprimere de sensu]".

Ultimately, it was a matter of taking a stance on the question of Cicero's theory of translation, which is based on a distinction between interpreter/translator and orator/author. In De finibus III.15, Cicero states:

It is not necessary to squeeze out a translation word by word, as ineloquent interpreters do, when there is a more familiar word conveying the same meaning. Indeed, I usually use several words to expose what is expressed in Greek by one, if I am unable to do anything else.

In De optimo genere oratorum 14, his argument is subtler:

I did not translate them [Aeschines and Demosthenes] as an interpreter, but as an orator, with the same ideas, forms and, as it were, shape, and with language fitted to our usage. In this I did not think that I should render word for word, but instead preserved every category and the force of the words. ${ }^{23}$

This distinction quickly gained currency among rhetoricians much loved by the humanistic tradition such as Horace and Quintilian, ${ }^{24}$ and came to represent the departure point for all subsequent debate on the topic in the Renaissance period. ${ }^{25}$ What was the role of the 
true translator? That of interpreter or of author? Was Cicero right? And if so, which Cicero?

This Ciceronian debate is often confused with the characteristically humanist debate on the question of Ciceronianism, where the purpose was rather to discuss the adoption of a language modeled on the style of Cicero and based on the idea of an intrinsic correspondence between res and verba, content and form. ${ }^{26}$ As the focus of discussion was whether or not it is necessary, when vulgarizing, to adhere to the words of the original text in order to express content, a question analogous to the one about whether certain verba are required to express certain res, the differences between these debates appeared negligible. Hence we see that the transposition of not only terms but also linguistic structures from the classical languages to the vernacular remained current as a subject of inquiry. ${ }^{27}$

Nonetheless, as we shall see, by the time these theories of vulgarization had taken root, the schism in the Ciceronian res-verba dichotomy had already played itself out. ${ }^{28}$ Objects and words were no longer on the same level, as the humanists had advocated - rather, objects and concepts were now prior to words, a position already argued by Aristotle. ${ }^{29}$ To ask why authors in the Cinquecento made no reference to the translation theories of the Quattrocento is thus misleading: Leonardo Bruni in his De interpretatione recta had totally different concerns when working on the translation from Greek to Latin in a context without the printing press. ${ }^{30}$ It would be like asking why Bembo in his Prose scarcely even acknowledged the experiences of Quattrocento intellectuals such as Leon Battista Alberti, Cristoforo Landino and Lorenzo de' Medici, and taking him to task for maintaining a certain kind of silence. Very simply, intellectuals in the Cinquecento had different questions and demands, as well as a profoundly altered theoretical framework to work with. $^{31}$

To reduce the whole question of vulgarization to a juxtaposition between word/ meaning and res/verba would be profoundly misguided. It would seem therefore more profitable to leave such distinctions aside for the moment, and to begin by looking at the different types of vulgarization.

\section{Ludovico Castelvetro on "traslatare"}

The first document to offer an insight into the question of the meaning of vulgarization is a letter dated 7 May 1543 from Ludovico Castelvetro to Gaspare Calori. ${ }^{32}$ There are at least three reasons why this document is of particular interest. Firstly, it is an early document written by a young Castelvetro which explores in an entirely theoretical vein the possibilities of translation and vulgarization. Castelvetro had yet to tackle the practical issues involved in translating classical texts: his Poetica d'Aristotele volgarizzata e sposta came out only in $1570 .{ }^{33}$ Secondly, the work was written at a time when the vernacular was still struggling to establish itself as a language of culture; Sperone Speroni's Dialogo delle lingue had been in print for only a year, although the ideas presented in it were already widely acknowledged, and the validity and dignity of the vernacular as a language capable of transmitting knowledge that is not only literary but also scientific-philosophical was under the constant scrutiny of philologists and humanists. Lastly, unlike the other documents that are examined here, Castelvetro's letter has the singular distinction, not to say misfortune, of remaining unpublished until 1747 when Angelo Calogerà brought it to light, sufficient reason for it not to have had any impact at all on subsequent debate. 
The letter has prompted a number of detailed studies, the purpose of most of which has been to shed light on the body of philological knowledge that was accrued from biblical or literary exegesis. ${ }^{34}$ What has generally been overlooked, however, is that Castelvetro focuses his analysis on the translation of literary texts - primarily poetry. Such compositions, in Castelvetro's view, had a single purpose: to entertain. Poetry has no other purpose, ${ }^{35}$ and in no way may it take on the task of uncovering truth or transmitting knowledge. This is especially true of the poetry of Virgil, which Castelvetro examines in his letter and openly attacks later in the Poetica d'Aristotele for its intent to transmit ideas, content and concepts that stray far beyond the remit of straightforward entertainment. ${ }^{36} \mathrm{He}$ is by no means alone in his views. Sperone Speroni held similar views in respect of poetic compositions, ${ }^{37}$ and it is an important point to make because the letter clearly shows that translation, too, at least in the field of poetry, must align with the ultimate purpose of the original. This implies the careful selection of words that are "ornate" precisely because they must give pleasure to the listener and the reader. Even so, it would be rash to conclude from this that every translation for Castelvetro must be "ornate". ${ }^{38}$

Castelvetro's letter is built around three core themes: (1) the genetic priority of concept over word; (2) the semantic power of concept over word; and (3) the impossibility of deriving the former from the latter. This impossibility gives rise to the single greatest issue in translation, namely its reliability. The problem is stated in psychological terms. While it is difficult to relate a word to a concept of our own, it is well-nigh impossible to do so with a word that replaces another word that already refers to another's concept. The impossibility of knowing the soul's concepts and affects - that is the intentions of the author - constitutes the first major obstacle to transmission. To transpose from one language to another is therefore always an act of authorship, because it relates one's own words to one's own concepts.

Castelvetro's glottological approach also presents a historical-cultural problem. Each language contains concepts that are in some way inseparable from words because throughout the course of the centuries they have built up a certain semantic value that can be transposed from one language to another only with great difficulty. These are the socalled "untranslatables". 39

The questions relating to linguistics and the theory of translation Castelvetro raises present no easy solutions, and one may well be lulled into seeing some kind of equivalence between thought/concept and linguistic utterance/word - a kind of nominalism, in other words, or one-to-one correspondence. ${ }^{40}$ This cannot be Castelvetro's position, however, because it would imply that only one specific word could be used to express a specific concept, hence no translation would be possible. Far more simply, Castelvetro speaks of a customary use of language, a kind of habitus. Just as we are accustomed to seeing water as transparent and find it strange to see it black, so we are accustomed to using certain words and not others for certain concepts. ${ }^{41}$ This is true not only for translation from one language to another, but also for periphrasis - in other words, when seeking to explain the same concept with different words in the same language.

Having established that it is easier to be composers or authors rather than translators, Castelvetro goes on to define a hierarchy of values for carrying out a good translation. Firstly, when translating it is necessary as much as possible to avoid terms that take one directly back to the source language, which above all else means eliminating 
Graecisms and Latinisms. Castelvetro's reasoning is that only in this manner can the vernacular genuinely see itself as a language worthy of science and literature without coming across as perennially subordinate to the classical languages. A case in point is the translation of " $\mu$ i $\mu \eta \sigma \iota \varsigma$ " as "rassomiglianza [similarity, likeness]" or more rarely as "rappresentatione [representation]", but never with the customary "imitazione [imitation]", which derives from the Latin imitatio.

Castelvetro offers no solution to the problem of the untranslatables, or of how to transpose from one language to another concepts that are closely bound to a word without resorting to loan-words from the source language. In such cases, which include the abovementioned question of the translation of " $\mu$ i $\mu \eta \sigma \iota \varsigma$ ", Castelvetro appears to be operating albeit unconsciously - in a manner that is highly philosophical rather than philological. The aim is to identify in the target language the word that best characterizes the source concept and then translate it. This naturally implies a deep understanding of the concept - an understanding which had hitherto remained unattainable given the impossibility of reading concepts stripped of words. The best that one can do to overcome this difficulty is to acquire an in-depth knowledge of the subject in question, namely the text to be vulgarized. However philological Castelvetro's approach may seem, and however closely he may focus on finding the right words, it is content, or the concept, that provides the key to his theory of translation. His works are intensely philosophical. In his view, one must have mastered both the source and the target language because otherwise one can give no account of the properties of translations, figures and qualities of words. To overlook the content would mean to create the paradoxical situation of expressing serious concepts with frivolous words, or frivolous concepts with serious words. To translate is thus to preserve above all content, then the terminology of the target language and, lastly, the syntax and linguistic structures of the source language.

On this basis, Castelvetro gives a reading of the passage from De optimo genere oratorum in which he states that Cicero refers to the role not of the translator, but of the orator, who is concerned more with content than style. ${ }^{42}$ This might explain Cicero's aversion to word-for-word translations - but still, according to Castelvetro, Cicero is not critical of literal translation in an overall sense; rather, Cicero wishes to assert that it is possible to adopt different approaches to rendering a source text according to the situation. Likewise, Aulus Gellius in his Noctes Atticae references the author/orator and not the translator when claiming that it is not necessary to translate a source text word-for-word. ${ }^{43} \mathrm{An}$ author for Castelvetro is not one who dresses concepts in words for the first time - at least, not only this. Like so many others after him, he refers rather to the etymological meaning of the word "author", which translates the Latin "auctor", from "auctus", perfect participle of "augeo", meaning "to enlarge", "to augment", "to develop" and "to expand". Anyone who is not a perfect translator, therefore, is for Castelvetro an author in the sense that he or she enlarges, augments, develops and expands the source text. It is not necessary to be innovative to be an author; any vulgarizer who is not merely a translator is an author, because he expands a source text, making it more transparent for the reader. As we shall see, Alessandro Piccolomini, too, adopts the approach of being an author, not a translator.

To conclude, there are two approaches to translation: one the interpreter's, the other the author's. Translation in a strict sense is the preserve of the interpreter, who must stick closely to the original text - and for this he must be expert not only in the 
terminology and syntactic structures of the target language but also in those of the source language. Knowledge of concepts through the words of source-language texts is crucial for an adequate translation using the relevant target-language terminology without inappropriate recourse to loan-words from the classical languages. This kind of translation requires not only philological expertise but also a great capacity to recreate the initial concept in other words, that is to say to understand the original concept in its most intimate sense and reproduce the same intimacy of understanding in the target language. This is why Castelvetro's translation of Aristotle's Poetics, aside from its critical apparatus, is not only philologically accurate but also a model of conceptual translation that represents the high point of his philosophical career.

\section{Faustus Longianus on translating according to Cicero}

Castelvetro's perspective is taken further by Sebastianus Faustus Longianus in his dialogue Del modo de lo tradurre d'una in altra lingua segondo le regole mostrate da Cicerone (1556), prompting Werther Romani to advance the not implausible hypothesis that there was in fact some kind of student-teacher relationship between the two. ${ }^{44}$ Be that as it may, Del modo de lo tradurre is the first published Renaissance work in the vernacular on the theory of translation. Bodo Guthmüller has already provided an admirable textual and contextual analysis of the dialogue, ${ }^{45}$ hence it is sufficient here simply to recall its theoretical relevance. The title itself clearly shows how the author's aim is to give an account of the method of translation advocated by Cicero rather than putting forward a general view of what it means to translate or vulgarize.

The fictional dialogue begins with the story of two intellectuals engaged in defending what they see to be the real task of the translator, namely that of interpreter or orator according to Cicero's text. In other words, Faustus Longianus is asking whether it is right to translate word-for-word or according to meaning. ${ }^{46}$ In order to take a stance in this debate, it is necessary from the outset to state what translation actually is and how it may be distinguished, for example, from metaphrasis, paraphrase, summary, comment, exposition and explanation - in other words, from the other modes of vulgarization.

Metaphrasis is, in Faustus Longianus's view, a form of popularization ${ }^{47}$ - whether in the same language or a different one - which comes close to translating according to meaning, so that, in his words, "nowadays it is used by many, but under the name of translation". "However, it refers only to "meaning or the shadow of meaning" - in other words, "it is not obliged to the purity of the meaning of the words". ${ }^{49}$ It can however be a powerful means of distorting the message of a text, and indeed it "amplifies, diminishes, confuses, transposes, disturbs, obscures, so that the main author would no longer recognize it as his own". ${ }^{50}$ The meaning can be transformed to such a degree that the original author finds himself on a par with a secondary author who may even bring another meaning to the text. Hence metaphrasis, whose purpose should be to adapt and explain the content to a wider audience, can end up perverting it instead. Elsewhere, Faustus Longianus speaks of metaphrasis in terms of an illustration (illustratitione) "which is not bound to any law of meaning or of words". 51

Like metaphrasis, paraphrase "can be carried out in the same language or in another one". ${ }^{52}$ It is in every sense a form of vulgarization because "its strength consists in clarifying 
the meaning of that which is ambiguous or obscure with a greater number of words" ${ }^{53}$ Unlike metaphrasis, therefore, paraphrase always remains close to the meaning intended by the author. Because of this, and because of its capacity to clarify content, paraphrase for Faustus Longianus is "extremely difficult, and not everyone can do it" ${ }^{54}$

Another form of vulgarization is the summary, or epitome, the purpose of which is to aid memory and ensure that only the most salient content is reported. Yet it is precisely in this selection of content that Faustus Longianus sees the greatest risk in the act of summarizing, which is liable "sometimes to cause no small amount of damage". 55 Selection can result in important content being left out or a message that is different from the author's intended message being conveyed. Hence the best summary is the one that follows the author's intended meaning.

The final form of vulgarization examined by Faustus Longianus is the explanation (ispianatione) or "ispositione, commentario, narratione, isplicatione". Its purpose is to

declare meanings, manifest the secrets of the art, resolve contradictions, clarify ambiguities, grasp the most plausible opinion in a controversy, publish stories and hidden fables, show the significations and virtues of words, apportion reason, discover their sources, observe their elocution. ${ }^{56}$

In other words, ispianatione serves to make the content of a text more plain, clear and understandable, and in this sense is an example of genuine vulgarization, even though "it may be undertaken both in one's own language and in that of others". ${ }^{57}$

Unlike all other ways of approaching a text, to translate means above all to interpret, convert and transpose faithfully from one language to another. In all other cases the original text may be modified in its own language. ${ }^{58}$

Translation is part of a wider psychological process based on a word-thing dichotomy of Aristotelian derivation: "any utterance that has ever been made or will ever be made by anyone anywhere in the world by voice or in writing consists of nothing more than two elements: things and words". 59 Things, meaning "statements, senses, feelings, matters, concepts, are considered first", prior to words, which are only an ornament to them; the priority is to preserve "the order of things", meaning concepts - that is to say, to not alter the sense of the original author's argument. ${ }^{60}$ Faustus Longianus is aware that "truth gets lost in differences, hence it is necessary gently to reason and make every effort to gain knowledge of the thing". ${ }^{61}$ Translation is always a betrayal, yet - despite this inescapable drawback of the translation process - a translator must spare no effort in revealing the truth of a text. Before anything else in the translation, the content must be preserved - and only subsequently is it possible to apply "the same forms and figures, or conformations, [...] ornaments, [...] or patterns". ${ }^{62}$ It is therefore necessary to translate "with appropriate words and beyond that to preserve the virtue, the force and the value of the words of the language from which one is transposing". 63 This means that words play a crucial role as a "garment" for concepts, and indeed Riccardo Drusi has argued for the existence "of an essential relationship between language and concepts, so that the word is a substance, not a vehicle, of the argument it expresses", 64 which is reminiscent of what has already been asserted by Castelvetro. Nonetheless, the bias in the relationship between concepts and words is still tilted in favor of concepts.

In the case of pure translation, however, the task should be to "stay within the words if possible and express the meaning" ${ }^{65}$ In other words, for Faustus Longianus translation 
should be word-for-word, if in such a manner the meaning may be conveyed. This is why he interprets Horace's "nec verbum verbo curabis reddere fidus / interpres" as follows: "you, who want to be a faithful interpreter, will not be concerned with translating word-forword, but will consider only the meaning". 66 "Interpreter" here does not mean "translator", however, because otherwise you would no longer have the priority of the wordfor-word translation. In this case, as in many others, "interpreter" is used by Faustus Longianus in its most commonly accepted meaning, which it retains to this day, of one who reveals in the best possible way the meaning of the source text as it is understood. ${ }^{67}$ Elsewhere he refers to the figure of the interpreter as an imitator, in opposition to the translator. $^{68}$ This discrepancy between translator and imitator gives some sense of how the problem of vulgarization is both anchored and unhinged by the problem of the imitation of Ciceronianism in the decades that spanned the fifteenth and sixteenth centuries. During this time, an "imitator" was one who followed the linguistic forms and structures of Latin, whereas for Faustus Longianus it is one who simply follows the overall meaning of the text.

Ideally, however, a translation should be word-for-word. Clearly this is not easily achieved: there is recognition of the fact that "each language has its own usages, beauties, splendors, which do not correspond to those of other languages" ${ }^{69}$ Hence in order to translate literally it is important to understand the meaning of the text, and to know both the language into which one is translating and the language from which one is translating. Whoever is unable to overcome these three difficulties will necessarily resort to translating according to meaning. ${ }^{70}$ It has been noted that his quibble here most likely has a specific target in mind, namely the anonymous translator of the Epistole famigliari di Cicerone, whose work appeared the year after Faustus Longianus's own translation. ${ }^{71}$ In its dedicatory letter, the process of translation is clearly represented as a vulgarization that seeks to transmit concepts rather than words. The reasoning runs counter to Faustus Longianus's: anyone who does not understand the concepts, so the argument goes, "opts to follow the path of the words [... ] attends only to the voices". ${ }^{72}$ It is often the case that those who do not understand the meaning of a text, and here the reference is to Faustus Longianus, go no further than the words, and so the "translation, which was discovered to make explicit otherwise hidden information, proves to be even more obscure". ${ }^{73}$ Translation is a form of vulgarization for the anonymous translator both because it must render into the vernacular and because it must clarify that which is obscure. The juxtaposition between the perspectives of the anonymous translator and Faustus Longianus is fictitious, however, an artifice created by the anonymous translator specifically to justify a new translation only one year on. As we have seen, translating word-for-word is possible and advisable for Faustus Longianus only where it is not at the expense of conveying the sense. Adherence to the text is important, but it must not constitute a betrayal of its sense.

In his Dialogo de lo modo di tradurre, Faustus Longianus identifies two general forms of vulgarization: those that simplify the understanding of a text - despite the problems that this too can sometimes cause - including metaphrasis, paraphrase, summary and ispianatione; and those that render the text into the vernacular, that is translation according to sense and literal translation. Vulgarization in the sense that simple texts which are also translated into the vernacular can be metaphrases, paraphrases, summaries and ispianationi if and only if they are in the vernacular. Translation, on the other hand - even though is not necessarily a clarification, since it represents a transition from a dead 
classical language to a living vernacular language - allows for a greater degree of communication of the content of the text.

\section{Francesco Robortello on vulgarization}

As the founder of Renaissance historiography and modern criticism with his In librum Aristotelis De arte poetica explicationes (1548) and De historica facultate (1548), Francesco Robortello is not known for his theory of vulgarization. Nonetheless, it is a topic he developed in at least two distinct ways. The first concerns the manner of translating from one language into another and explains how to make philosophical discourse "popular", be it in Latin or vernacular. It is dealt with in the manuscript Del translatare d'una lingua in l'altra (c. 1552). ${ }^{74}$

In this work Robortello distinguishes between two kinds of vulgarization: one concerning the sciences, the other common speaking. For Robortello this distinction comes from the first book of Aristotle's Rhetorica, where the Stagirite deals with the possibility of speaking according to either the "common place" or the "proper place" of a particular science or art. ${ }^{75}$ Robortello understands this doctrine of Aristotle's as a theory of vulgarization, which can be scientific or common to a greater or lesser degree. While in Aristotle's mind "common" means general or universal, for Robortello it has come to mean "popular". ${ }^{76}$ Robortello's conceptual shift is evident from his distinction between scientific and common speaking. ${ }^{77}$ Common speaking is therefore like a plain that may easily be traversed, in that it is easy to understand and learn, while scientific speaking is like an intricate vineyard, often repetitive and hard to understand. Sciences must be translated distinguishing universal and scientific terms such as "substantia", "qualitas" and "predicamentum", still nowadays valid, from ancient words such as "toga", "paludamentum" and "logio". Universal and scientific terms, Robortello states, "must be translated in our language in terms coined by the translator according to the meaning of the word, that is, orator, 'dicitore"' ${ }^{78}$ As much as possible Robortello wishes to avoid the wholesale use of Graecisms and Latinisms, preferring rather to search for the equivalent vernacular terms that best express the essence of the concept. In this sense, Robortello is very close to Castelvetro. Unlike Castelvetro, however, Robortello distinguishes between a number of different levels of translation precisely because translation is not merely the transposition of words from one language to another, but involves a wider process of vulgarization. Scientific terms can be translated into "our" popular terms, or into "our" terms that are not in current usage, or into ancient terms that have been "popularized or accepted by people out of necessity", or into ancient terms that are "not made popular". What is important for Robortello is that these terms must in every instance be comprehensible to all. But he also takes this distinction a step further.

Ancient terms that refer to the same thing must be translated with vernacular terms. For example, "ephippium" must be translated with "sella [saddle]", but ancient terms that are similar to those ordinarily employed must be preserved using vernacular diction, such as "due sesterzi" or "cinquanta ducati", thus preserving a Latinized vocabulary in the vernacular. Alternatively, if there is no correspondence in terms of terminology or content, it is necessary to preserve ancient words as they are. This is important for Robortello especially in connection with ancient arts and sciences which have specific terms and subjects no longer current. This explains in general the strategy for using 
Greek and Latin words in vernacular texts: it is not because the beneficiaries of these texts are more learned, but because there is no other way to teach the people, if not by indicating with precision what no longer exists and what had its own specific term. Only thus, according to Robortello, is it possible to disseminate knowledge easily and to educate people.

Common speaking proceeds, on the other hand, by means of simple words, locutions and metaphors. Simple words do not constitute the difficulty of translation, while locutions may be of different kinds. Proper or ordinary locutions like "conticuere omnes [all were silent]" can be translated without difficulty into the vernacular. ${ }^{79}$ Locutions of circumstance, if there are analogous vernacular terms, must be translated thus - otherwise they can remain in the original language. For instance, the locution of circumstance "Diffugere nives, redeunt iam gramina campis [The snow has fled; already the grass is returning to the fields]" can be translated, but such expressions sound infelicitous in the vernacular. ${ }^{80}$ Fabular locutions (locuzioni fabulari) such as "indulgere genio" or "Bacchus amat colles" are readily translatable. ${ }^{81}$ Metaphors must be translated only if there are words analogous to the ancient ones, otherwise they do not need to be translated - although one should find in one's own language equally effective metaphors so that the knowledge may fully be understood.

Robortello's conception of the translation of knowledge is far from simple: one must translate, it is true, but not always, not necessarily and not unconditionally. There are various ways of translating, and various linguistic registers must be adopted in order to render in the best possible way the sense of what is being translated. This means not only remaining faithful to the original, which for Robortello is the main priority in terms of acquiring reliable knowledge, but also being understood by a wider public. Robortello's theory of translation is therefore a genuine product of his idea of the popularization of knowledge, but also of his philological approach, which demands high-quality knowledge, not cheaply bartered goods.

From this idea derives also the conception of how to vulgarize - in other words, in this case, how to make a philosophical discourse popular. ${ }^{82}$ Robortello's underlying Aristotelianism plugs into Cicero's theory of the orator as translator, or vulgarizer. For this reason his whole discourse on vulgarization centers on the problem of rhetoric, which for Robortello is useful for making philosophical discourse more understandable and popular among a wider public: a philosophical discourse is that which is constituted by words, such as universal terms, that are little known to the populace; and on the contrary, popular discourse is that which refers directly to things whose words are instantly comprehensible and shared by all. For Robortello rhetoric is particularly necessary in education and teaching, in other words as a means of introducing everyone to the knowledge of things.

Rhetorical discourse, which deals with truth, is specifically called "oratorical" in the Ciceronian sense, which sees in the orator the vulgarizer of knowledge. Unlike the discourse of philosophy, oratorical discourse must have a certain degree of eloquence for Robortello. In fact, it has the task of making knowledge clear and giving the populace the opportunity to judge "concretely" the truth or falsity of what has been seen. ${ }^{83}$ In order to convey truth, philosophy usually employs a sophisticated process, capable of generating knowledge for the populace. The oratorical method, conversely, is suitable for popularizing philosophy because it starts from probable premises - or at least from 
what may be taken to be true by the populace, since the populace itself can start from a common and shared body of knowledge and then further refine what it has learned. ${ }^{84}$

Not all knowledge can be popularized, according to Robortello. Indeed, there are some disciplines such as jurisprudence, mathematics and theology which in themselves can also be eloquent but which common people find it difficult to get used to, primarily because they employ so many technical and specific terms that cannot be made popular. ${ }^{85}$ This has given rise to the belief that Robortello maintains the idea of possible popularization purely for certain topics that are of ordinary interest to people. Not only in such instances do common people learn in a peculiar manner: they acquire knowledge exclusively through oratorical discourse, which is limited neither by brevity nor by the use of specific technical terms. In general, however, Robortello points out that it is important to follow the rules when explaining the specific terms of the various arts and sciences, referring first to the Greek and Latin meanings and then giving a translation in the common language. ${ }^{86}$

In De artificio dicendi Robortello maintains that there are four ways of making a philosophical discourse popular, in other words of transforming an intellectually challenging philosophical text in order to make it relevant to a wider audience. The first of the four ways is to make an abstract notion more concrete, which is possible thanks to the rhetorical inference of the example. The second way is to transform a universal concept into a particular concept: the orator does not deal with happiness in terms of its definition, but with regard to the happy man. ${ }^{87}$ The third is speaking of philosophical concepts by means of metaphor. The fourth is to employ many words and phrases, that is circumlocution, to explain and clarify a philosophical concept. A philosopher should not overdo words and metaphors, thereby risking falling into error and making the discourse more obscure, but the orator can use this technique to explain more than once and more effectively notions that are not completely clear to the populace. ${ }^{88}$

Rhetoric for Robortello is a tool for reaching a wider audience, and popularizing, vulgarizing and translating are first of all processes by means of which the public's level of knowledge may be raised without reducing high culture to a lower level. ${ }^{89}$

\section{Alessandro Piccolomini on translation}

Never having attempted a translation into the vernacular, Robortello presents a view that is entirely theoretical. Alessandro Piccolomini, however, explored practically every conceivable form of vulgarization during the course of his life. His theoretical considerations may be found in the Epistola ai lettori del modo del tradurre, published in Piena, et larga parafrase nel terzo libro della retorica d'Aristotele (1572). ${ }^{90}$

The roots of Piccolomini's theory of vulgarization reach back into Aristotelian psychology. He is convinced that the concepts of the mind - meaning the passions of the soul - are the same in all human beings and that they have psychological priority over words. Indeed, words are found only to give expression to concepts, not vice versa. At the same time, concepts form the primary content of texts and, hence, those engaged in vulgarizing should work so that "their preservation be kept always clean, immaculate, inviolable and in no way altered". 91 To change concepts when vulgarizing can lead to the interpolation of the voice of a second author into the text, who "would come to write his own things [... ] would stray into the vice of falsifying [... and] would make others say what they 
do not say". 92 The priority for Piccolomini, as it was for Castelvetro and Faustus Longianus, is therefore to preserve the concepts. A more difficult proposition is to maintain the locution, "which consists of words and structure and in the links between them", because every language has its own specific variety. ${ }^{93}$

Concepts may be vulgarized in different ways: "translating, commenting, in other words explaining, annotating, paraphrasing and summarizing". ${ }^{94}$ Of all these methods, the most difficult - which, in Piccolomini's opinion, is also the one to avoid - is translation. The perfect translation "forces one to maintain and preserve not only the opinions of others, but also their words", an operation which, as we have said, is extremely difficult to achieve.

The pitfalls are manifold. In Piccolomini's view, if one does not translate but instead limits oneself to commenting, paraphrasing, summarizing and/or annotating, one requires expertise only in the source language, not so much the target language, because these forms of vulgarization do not require adherence to the original and therefore the words can be less rigorously selected. Vulgarization generally, when not pure translation, allows the sentences to be expressed more effectively - broken down, simplified and modified - so that the effect the author intended becomes more understandable in the target language. Hence vulgarization does not require "an exceedingly close familiarity with the language". ${ }^{95}$ On the contrary, in translation absolute correspondence between source and target languages is required.

Translation has another limitation. In every form of vulgarization, from comment to paraphrase, the vulgarizer may be accused of betraying the author. In comments and paraphrases, however, a betrayal may be viewed as an instance of bad interpretation, a form of accusation mitigated by the common practice - in these types of vulgarization - of the vulgarizer speaking in the first person. With translation, however, as mentioned above, the vulgarizer is never accused of bad interpretation: he can only be a falsifier.

Piccolomini's preference for types of vulgarization other than translation is also dictated by practical concerns. Translations are so difficult, especially those that set themselves "to convey from one language into another scientific and doctrinal material", that often the translator simply ends up displaying his ignorance of the subject and his inability to use the appropriate language. ${ }^{96}$ In other words, Piccolomini takes issue with the approach of literal translation carried out by translation professionals who are not experts in the subjects they are meant to vulgarize, rendering texts virtually incomprehensible.

Unlike other forms of vulgarization we have seen, translation must not only remain faithful to the mind of the author but must also "preserve as much as possible his words and locution and links, and his thought patterns" without needing to further amplify or order sentences. ${ }^{97}$ Adherence to the source language can sometimes produce a translation that is "more obscure or more confused", and ultimately "pointless and vain", therefore bearing "no fruit whatsoever". ${ }^{98}$ Piccolomini's argument here is with the translation of Aristotle's Poetics by Ludovico Castelvetro. ${ }^{99}$ Piccolomini even goes on to add that translators of scientific texts working from Greek into Latin, or from Greek into Latin and then into vernacular, even when extremely well versed in the content, frequently in attempting to stay close to the word of the original fail to achieve the ultimate aim of the translation, which is to vulgarize - in other words, to make the content more understandable: 
some [...] without conveying, as they should, primarily the sentence and the sentiment, proceed word-by-word, minimal particle by minimal particle, seeking to reproduce the exact rhythm they find [... and] end up producing a kind of confused and insipid locution, and what is worse, [one that is] for the most part unintelligible [... they render] the sentence obscure, intricate and often false, and, what is worse, as I have said, difficult to draw any sense from. ${ }^{100}$

Moreover, Piccolomini rejects the position of those who do not wish to make any kind of modification to the original text and end up formulating new words in order to consolidate meaning, thus creating "barbarisms". He also attacks the practice of those who attribute the meaning of one word to another, and in so doing mislead the reader. ${ }^{101}$

To conclude, it is by no means the case that Piccolomini rejects translation as a type of vulgarization; he simply believes it to be more difficult to produce. As with all the other theoreticians of vulgarization and translation, what must be preserved above all else in scientific works is the content. In Piccolomini, more than elsewhere, one perceives the influence of his experiences in the Accademia degli Infiammati, where a concept was sufficient to gain access to content. The other authors considered thus far, as with those still to follow, believe that in order to access the truth and make the concept understandable it is necessary to restore the word to its full originality.

\section{Orazio Toscanella and the Discorso del tradurre}

Anyone expecting to find an original theoretical position in Orazio Toscanella will most likely be disappointed. The ideas he develops in his Discorso del tradurre, published in 1575, are not dissimilar to those of his contemporaries. As with Faustus Longianus, the choice as to whether or not to translate and vulgarize needs no justification for Toscanella: everyone "knows that transposing authors from one language to another is both extremely beneficial and highly honorable; for this reason I need spend no effort demonstrating it". ${ }^{102}$ Moreover, for Toscanella the problem of vulgarization, as he himself addresses it, is restricted to translation - and, in particular, to the translation of philosophical and scientific texts.

From this perspective, the essential element that the translator must seek to preserve before all others is the content. Indeed, Toscanella's first requirement is that the translator be an expert in the subject he is translating, lest the end product turn out to be of extremely poor quality: "if someone who is not a philosopher started translating works of philosophy, and someone who is not an astrologer works of astrology, there is no question that he would reap criticism rather than applause, and in no small measure". ${ }^{103}$ But it is not merely a problem of content: there is also the matter of terminological appropriateness, since the various sciences use different vocabularies and to mix them up would be to distort the translation - hence his advice that "no one should undertake the translation of something that is outside of their profession". 104

Unlike Piccolomini, Toscanella believes that the translator not only requires an extremely extensive knowledge of the source language but also an "excellent taste for the language into which the thing is being translated". ${ }^{105}$ Nonetheless, he sets no distance between himself and the other theorizers of the time when he asserts that the translator must have a good grasp of "the topics addressed by the author that he intends to translate". 106 
Having advanced such general considerations, Toscanella then returns to the passage from Horace so dearly loved by Faustus Longianus: "nec verbum verbo curabis reddere fidus / interpres". Toscanella distinguishes between the imitator, known also as the orator, and the interpreter or translator. Despite a close "kinship" between the two, "the imitator must not remove the words and the objects of the one he is imitating [...] but while imitating well he must use a different invention, disposition and location from that of the person he is imitating". ${ }^{107}$ The imitator must therefore be seen more generally as a kind of vulgarizer who is not bound to the letter of the author but, rather, is occupied with ensuring that the content is perfectly understandable. By contrast, the interpreter "must be faithful, because his law is to explicate word-for-word, according to the properties of Latin or Greek or another language": he is therefore an "explicator and translator" 108 The use of the verb "explicate" by Toscanella must not lead us into the error of seeing a false correspondence between the translator and he who provides explanations, clarifies and makes content understandable. The latter is only and properly an imitator, or - in more explicit terms - a commentator. The task of the interpreter or translator is to explicate in the sense of the Latin verb "explicare", meaning to render a discourse in the vernacular following the rules of the source language. Hence in Horace's passage "interpres" is not properly speaking the interpreter, but the imitator or orator, so that the sense of the sentence may be translated as "do not expend yourself translating word-for-word like a faithful interpreter, just imitate". ${ }^{109}$

The task of the real translator is to stick rigorously to the words. He must translate literally and not "(as others would have it) according to substance". ${ }^{110}$ The openly polemical "as others would have it" is probably directed at Piccolomini, but this does not mean that Toscanella is giving priority to words over content. The translator must be as faithful as possible to the words, because words represent things and different words represent different things. In this Toscanella displays a naturalistic view of language, rather like Castelvetro: he believes that certain concepts remain perennially unchanged and stand in a univocal relationship with certain words. Unlike Castelvetro, however, when translating, the same concept should be translated with the vernacular term that most closely corresponds to the original word, not concept, in the target language. But Castelvetro prefers terms that are not calques of the source language if the translator can identify alternatives in the target language that appear to be more suited to expressing the concept. If concepts are essentially more or less the same, then the words that are used should also be more or less the same. For example, whereas Castelvetro prefers to translate "imitare" with "represent", Toscanella prefers first "imitate" and then "represent". ${ }^{111}$ Likewise, "cognitio" was to be translated primarily with "conoscenza", using "intelligenza" only as a secondary option. ${ }^{112}$ There are plenty of such cases in the Prontuario di voci volgari et latine, a text which has been unjustly neglected by historians of language. In his Discorso, Toscanella points out that the target language must not only reflect the "quality of the words" but also the "quantity of their syllables, and the position where they are collocated". ${ }^{113}$ For instance, "lucidus" must be translated with "lucido" rather than "chiaro", not merely because of the quality of the word but also because of the number of syllables: "lucido" has three syllables like "lucidus", whereas "chiaro" has only two. "Lucidus" could also be translated with "lucente", which has the same number of syllables - but "lucido" is preferred nonetheless "out of respect for the nature of its syllables, which in 'lucente" are long and in 'lucido' are short". ${ }^{114}$ The correspondence must be of such quality and 
detail that not only must the words and syllables be the same in number and of the same length in order to deliver the same timing and the same level of harmony, but the words themselves must be positioned in the very same place within the sentence: the translator is "obliged to position the translated vernacular verb where the Latin verb is, the noun where the noun is, the pronoun where the pronoun is, and so on with all other parts of the discourse". 115

This level of correspondence must be maintained regardless of the differences between languages:

the Moors, the Persians, the Indians, the Arabs, the Chaldeans, the Greeks, the French, the Spanish, the Italians, and all the others use different languages, yet each in his own language has the words to name practically every single thing. ${ }^{116}$

In other words, "each nation has sufficient words to express almost all things". ${ }^{117}$ What is striking about Toscanella's argument is not so much the fact that each language is sufficient and therefore worthy of expressing anything, but rather the failure to acknowledge the link between the progress of knowledge and the development of language, as though language did not evolve with the advancement of knowledge and was itself static - a link that is very clear in Piccolomini. Since knowledge is no different from that of the Latins in other words, since content and concepts are the same - in Toscanella's view there is no problem with using words in the vernacular that correspond to words in Latin.

What matters most to Toscanella is to be as faithful as possible to the original text. Sometimes, in order to sustain such faithfulness, the translator may use obsolete words or refer to things that no longer exist and are therefore difficult to understand. This may be achieved if and only if "he has some support, and knows that someone else has used them" or that they can be "received and tolerated". ${ }^{118}$ Moreover, if certain words cannot be translated into the vernacular "they can be left without blame, just as they are, in the same way as the translators of Greek into Latin left certain Greek words as they were". ${ }^{119}$ If it is not possible to adhere so closely to the text because certain concepts and ideas would prove incomprehensible, the translator may use "periphrasis, or metaphor", or other rhetorical devices that will render a text more intelligible. ${ }^{120}$ Such techniques, such "roundabout expressions", must not be overused, however, because "simple things in every language may be called in simple ways". ${ }^{21}$

Toscanella seems somewhat critical of those who, with the excuse of making a text more understandable, want to embellish it with ornate "figures and selected concepts" when translating. This operation makes sense - but not always. Using a colorful metaphor, Toscanella claims that a prostitute will not necessarily appear more beautiful the better dressed she is. On certain occasions her garments will prove inappropriate - for instance, for a marathon, her ornaments should be set aside. Likewise, "those garments and those jewels and ornaments that make some things extremely beautiful, are unbecoming to others". ${ }^{122}$ It is futile and vain for Toscanella to reiterate that the translator must respect the nature of translated things: this is the fundamental principle of translation, otherwise the translator would not even undertake the task. Ultimately, it appears obvious to him that translation has the purpose of making content known and is not merely a literary and linguistic exercise. With that said, the special edge that translation has is its complete faithfulness to the source text. On the other hand, it is his view that anyone who states that sentences written in the classical languages cannot be translated 
into the vernacular in a way that is just as beautiful and refined is effectively saying that "the Tuscan language is not poor, but exceedingly poor, and that it cannot reach the meaning of the Latin language without roundabout expressions". ${ }^{123}$ In other words, for Toscanella this is tantamount to questioning the value of the vernacular as a language of culture capable of competing with Greek and Latin.

At the end of his Discorso, Toscanella finally shows his cards when he says "that the translator must preserve the same invention, the same disposition and the same locution observed by the author" ${ }^{124}$ He does not deny the importance of transmitting the content, something he considers to be beyond question, but he focuses more on the language and the style - in other words, on the rhetoric of translation.

\section{Girolamo Catena on the translation of sciences}

Another advocate of this view who has experienced something of a comeback in recent years, albeit more in the context of comparing contemporary translation theories than providing genuine historical contextualization, is Girolamo Catena. ${ }^{125}$ Compared to the authors examined previously, the theoretical influence of Bembo is far stronger in Catena. In his letter of 27 July 1583 addressed to the Archbishop of Otranto, Marcello Acquaviva, Catena rebuts the identification of the vernacular with the language of the people, as does Bembo himself in his Prose della volgar lingua. The true vernacular is not Italian, or Tuscan, or Florentine, but the Florentine codified by the great writers of the Trecento such as Petrarch and Boccaccio. When writing in the vernacular, therefore, the rules laid out by these authors must always be followed:

it is not permitted to change and write according to one's own caprice, fishing from the scum of the populace and the plebs, as so many modern writers do [...] who betimes write and teach something worthwhile when imitating Petrarch and Boccaccio, and following their example; but at others prove themselves to be both lacking and crude. ${ }^{126}$

From this it is clear that vulgarization must follow "the manners of figurative speaking and the compositions of voices" - or, in other words, it must contain a degree of rhetoric. ${ }^{127}$

Catena had already outlined some of these ideas in his Discorso sopra la traduttione delle scienze, \& d'altre facultà, published in 1581, where he applied them specifically to the translation of scientific-philosophical texts and Scripture. The work opens by making a clear distinction between interpreter/translator and imitate/orate, concluding that "it is not necessary to use many words to talk about something". ${ }^{128}$ Although his observation appears self-evident, Catena returns repeatedly to this contrast throughout his Discorso with a view to differentiating between generic forms of vulgarization and specific forms of translation.

The primary aim, however, is to define the purpose of translation, which can only be to "benefit others by highlighting those authors who by universal consent have been approved and considered perfect, so that we may learn from them the true manner of composing and learning the right doctrine". ${ }^{129}$ Catena thus reveals his main concerns: firstly, to learn to compose in a certain manner and, secondly, to learn good doctrine. The rhetorical and stylistic factor is not separate from the content, but it does enjoy a certain priority over it - at least initially. It is therefore no surprise that for Catena "the proper translation and interpretation of the authors in their doctrines was [... ] word-for-word". ${ }^{130}$ Translating word-for- 
word means essentially "to preserve the figures and the same order of things", thus prioritizing rhetoric over content. ${ }^{131}$ The content may be conveyed only through a perfect rendering of the words. Hence, he asks: "who will give me the true science of Plato or Aristotle if he does not restrict himself to interpreting word-for-word?" 132 Only the words render the true meaning because they give back the concepts.

Free translation, on the other hand, constantly fuels the suspicion that the author may not actually have said what has been translated. How, asks Catena, can one learn to write poetry like Virgil if the translator "translates less than faithfully? In this manner I would be imitating the translator, not the author". ${ }^{133}$ The example is significant because it concerns poetry rather than scientific prose. Whether or not this rule is universal is an entirely legitimate question, and quickly receives an affirmative answer:

it has always been agreed among the experts that in the public schools one reads the ancient translations of Aristotle, whether by Boethius or others, never a modern one [...] since the translations of the moderns, for all that they are cleaner and more ornate, precisely because of their ornaments lose the true sentiment of the author. ${ }^{134}$

Following the words is therefore the only way to gain access to the truth of the text: the truth reveals itself through the words, not only through concepts. Hence "the sciences and the doctrines and even more so the Holy Scriptures must be translated according to the words, even when the outcome would prove less easy on the ear than one's own composition or an imitation". 135

It is therefore necessary to distinguish between the "simple interpreter", meaning the translator, and the "interpreter orator". Few in Catena's view have even noticed this distinction, especially among the early translators of "the Metamorphosis of Ovid and the works of Virgil, the comedies of Plautus and Terentius and other works of primary importance such as the Ethics of Aristotle and others" ${ }^{136}$ The most likely suspects are Giovanni Andrea dell'Anguillara, Alessandro Piccolomini, Ludovico Dolce and Giovanni Fabrini, who stand accused of replacing the voices of the classical authors with their own. ${ }^{137}$

Hence Catena's desire to make the distinction clearer. The "simple translator finds for each word its correspondent, and orders them in the same way, rigorously preserving their form, in other words the layout of the sentences and likewise all the figures". ${ }^{138}$ The translator/orator is different from the simple translator because by "using figures and words that are appropriate to the applications and customs of the language into which he is translating, he has no need to count the words". ${ }^{139}$ The translator/orator is therefore distinct from the simple translator because he follows the rhetoric of the discourse, but not the same words. The translator/orator is not be confused with the orator, or imitator, as was the case in the authors we examined earlier. To translate as an orator is different from being an orator.

There are also translators who consider themselves translator/orators, but in fact are not:

some, believing they are illustrating places, add their own inventions to such a degree that they corrupt the art, and what there is that is good, and the work they have accomplished is not translation nor imitation nor comment nor paraphrase nor summary nor any other such form, but a truly monstrous body. ${ }^{140}$

Catena is particularly scathing of the false translators of Aristotle, "who to a very great extent and with great eloquence have translated him, thinking they were illustrating 
him". ${ }^{141}$ His reasoning is quite singular: "philosophy is like an immaculate virgin that loves neither compliment nor ornament" ${ }^{142}$ Regarding scientific-philosophical texts, Catena recommends that a vulgarization go straight to the heart of the content without any rhetorical ornament whatsoever: "eloquence is not necessarily to be sought in the doctrines, or where truth only resides". 143 This is not to say that he is giving up on the rhetoric of the discourse, however, which must be kept in the translation to reflect the original. Catena openly attacks those who seek to translate an author's arid voice with a style that is flowery and abundant just for the purpose of "being viewed as good Ciceronians". ${ }^{144}$ Anyone who translates by departing significantly from the words of the author for the sake of rhetoric may consider themselves to be "ignorant" or "forgers". ${ }^{145}$ In this group, Catena points the finger at one translator of Aristotle in particular, Joachim Périon, who - as Charles B. Schmitt has pointed out - created with his beautifully Ciceronian translation a full-blown "humanist Aristotle" in opposition to the "scholastic Aristotle", who at times is even more obscure. ${ }^{146}$ As Catena observes, the style of Aristotle was "succinct and restrained", while Cicero's was "extremely elaborate and abundant": in order to be faithful to these two authors, therefore, one must translate their works word-for-word in different ways. ${ }^{147}$

As we have seen, Catena's interest in literal translation is due to the fact that it alone renders the words of a discourse in a perfect way. It would however be misguided to think that translation for Catena is a means of making the discourse of an author understandable, or even simply to make it more easily understood. To translate is most definitely not to vulgarize in the broadest sense of clarifying or popularizing. There are instances in which one can and must translate in an obscure manner, the most noteworthy example being Heraclitus:

if I were to translate Heraclitus, and my translation were to remain obscure, what blame would I have, given that Heraclitus wanted to write obscurely. On the contrary, it would no longer be a composition of Heraclitus's if I sought to open it up. This is the task of the commentator, not the translator. ${ }^{148}$

One must therefore not confuse translation with other types of vulgarization, such as epitome, summary and paraphrase, which have nothing at all to do with translation, except perhaps free sense-translation, sensu lato, where texts "are not formally translated". ${ }^{149}$

And it is precisely in order to distinguish literal translation from other forms of vulgarization - sense-translation in particular - that Catena identifies five specific types of wordfor-word translation:

When the layout is observed, and all the words are interpreted according to the order; when one transposes, but all the words are translated; when each word has its correspondent of the same quality; and even if it does not, the same Greek word is used; and of the language into which one is translating $[\ldots]$ the language of the orator $[\ldots]$ which is done circuitously, $[\ldots]$ namely with a great roundabout use of words. ${ }^{150}$

As is to be expected, Catena doubts that the last two forms of translation are indeed wordtranslations, suggesting rather that they fall under the broader umbrella of vulgarization, which "belongs more properly to paraphrase, and to those who do epitome, and summary, and breviarii". ${ }^{151}$

So Catena identifies three types of vulgarization, two of which are translations proper, the third not. There is literal, word-for-word translation, which is pursued in order to stay 
faithful to the original text. There is also oratorical translation, similarly defined as free, where the aim is not to translate word-for-word but to deliver a translation of the text that is faithful to form and structure, while focusing exclusively on the style of the target language. Lastly, there is imitation, where the sense and the content of the text are maintained without any concern for the form, structure, words or rhetoric of the discourse. These three types of translation may be traced back at least to humanism, for instance the work of Emanuele Crisolara:

Manuel used to say about translation that to translate ad verbum into Latin [conversionem in latinum ad verbum] was wholly ineffective. It was not only absurd, he averred, but even sometimes, perverted the sense of the Greek. One must translate according to the sense [transferre ad sententiam], he said; those who took pains with matters of this sort would in this way make it a rule for themselves not to alter in any way the propriety of Greek usage. For if anyone alter [immutarit] some [part] of Greek propriety with the object of speaking more clearly and brilliantly to his own people [i.e. to those who spoke his own language], he is playing the part of a commentator [exponentis] rather than of a translator [interpretis]. ${ }^{152}$

As Sabbadini has noted, "here in conversio ad verbum we can see literal interpretation, in transferre ad sententiam faithful oratorical translation, in immutare the free oratorical translation". ${ }^{153}$ It is a singular inversion of values. Whereas Crisolara preferred oratorical translation because it allowed him to showcase the beauty and eloquence of the Latin language (we are referring here to translations from Greek into Latin), Catena believed that literal translation was better for preserving the truth of the message. In this sense Catena's approach is no different from that of Piccolomini's; whereas the latter believed that the word was not indispensable for the transmission of the truth, in the opinion of the former only the word could adequately express the truth of a text. Both, however, wished above all to deliver the truth and the sense of the discourse of the author.

\section{Conclusion: philologism of content}

From this examination of the treatises that deal explicitly with the theory of vulgarization and translation, we can state unequivocally that to vulgarize does not always mean to transpose into the vernacular, namely to translate, but can sometimes also have the broader meaning of popularizing. Hence not every translation is a vulgarization.

Experts have often held the view that the focus on translation, literal translation in particular, was a reaction to the spread of vulgarizations that seemed in one way or another to betray the original text through amplification or summary, sometimes even by completely disrupting its content. This resistance undoubtedly echoes the intellectual debates that were current at the time, but when taken to extremes it ends up obscuring the sense of vulgarization and translation which everyone could agree upon, which was the manifestation of the content of knowledge. Authors such as Piccolomini did so openly, without concern for the words, and in this way were able to explore alternative forms of vulgarization. Those who had a more naturalistic conception of language, however, and believed in an intrinsic correspondence between concept and word, tended more towards literal translation. The choice to translate word-for-word is dictated by a specific desire to convey the truth expressed by the original text. One can speak in terms of philologism of content rather than the word, by far the more common interpretation. What matters here is 
that we are not discerning a perspective in which external expression (the word) is privileged over or juxtaposed with internal content (the concept). This would be to simplify the positions of these authors. The word is always geared toward the transmission of the content.

Hence we might be led to conclude that these authors, with their focus on the correspondence between words and content, in some sense brought about a renaissance of the humanistic ideal of the union between res and verba. Yet here too the conjecture would be misleading. The purposes of the humanists were different from those of the intellectuals of the late Cinquecento; whereas the humanists preserved the unity of res and verba because they were intent on a type of language that highlighted the eloquence of a discourse, their later counterparts upheld the union of res and verba as the only means of rendering the truth of the content with the utmost fidelity. With the former there is an underlying Ciceronianism which is almost entirely absent in the case of the latter.

Ultimately, then, what did it mean to vulgarize in the Renaissance? As regards both translations - of whichever kind - and other forms of vulgarization, it meant rendering in the vernacular for the purpose of making content more accessible. Content is never at the expense of rhetoric or the eloquence of the discourse. What matters most is the transmission of sense, and in order to transmit sense it is legitimate also - in the more extreme cases - to abandon literal translation, which can be cumbersome, and embrace free forms of vulgarization. Naturally, vulgarizers were also aware that this would lead to a betrayal - but betrayal, as mentioned at the outset, can also lead to new traditions and ideas, an acceptable sacrifice for the advancement of knowledge.

\section{Notes}

1. As late as the early 1900s, Remigio Sabbadini believed that the first to use the term tradurre (from the Latin traducere) with this new meaning was Leonardo Bruni in 1405; see Sabbadini, "Del tradurre i classici in Italia". This is an opinion that has been upheld even in recent studies: see, for example, Norton, "Humanist Foundations of Translation Theory"; Trovato, Storia della lingua italiana, 149. Today we know of prior occurrences in the vernacular - for instance, Guido da Pisa in the Trecento - even though they were isolated cases; see Guido da Pisa, Fiore d'Italia, 7.

2. By the term "people [volgo]" I mean the class in a society that represents the greatest number of people and commands the greatest anonymity, but also occupies the lowest levels of culture, and hence also contains the least qualified and important individuals in respect of economic and political life. It may be synonymous with popolo in being the part of society that is juxtaposed to the upper classes; see Sgarbi, "Aristotle and the People".

3. To make a text clearer does not necessarily mean to simplify or trivialize it. For example, Lodovico Castelvetro's Poetica vulgarizzata et sposta (1570) clarifies the Aristotelian text without trivializing or simplifying it. On the other hand, Giovanni Antonio Roffeni's Discorsi astrologici (1609-1645) both simplifies and trivializes Aristotle's natural philosophy.

4. Steiner, After Babel, 449.

5. See Paris, "Translation and Creation"; De Campos, "De la traduction come création"; Hewson, "Vexed Question of Creativity".

6. I refer here to the "public" rather than readers because it is now an accepted fact that reading in the Renaissance was not the only approach to a written text, as oral transmission was still very much an active phenomenon.

7. Segre, "I volgarizzamenti del Due e Trecento"; Contamine, Traductions et traducteurs; Guthmüller, "Die volgarizzamenti"; Folena, Volgarizzare e tradurre; Beer, Translation Theory and 
Practice; Beyers, Brams, and Sacré, Tradition et traduction; Hamesse, Les traducteurs au travail; Morlino, "Volgarizzare e trasporre".

8. Cortesi, "La tecnica del tradurre".

9. Norton, "Translation Theory in Renaissance France"; Norton, Ideology and Language; Worth, Practising Translation; Worth-Stylianou, "Translatio and Translation".

10. Guthmüller, "Literaturgeschichte und Volgare"; Guthmüller, "Letteratura nazionale"; Guthmüller, "Antico-moderno, latino-volgare".

11. Some examples include Guthmüller, Ovidio Metamorphoseos vulgare; Porro, "Volgarizzamenti e volgarizzatori”; Borsetto, L'Eneida" tradotta; Borsetto, Il furto di Prometeo, 222-55.

12. Tesi, Aristotele in Italiano; Cotugno, "Piccolomini e Castelvetro traduttori della Poetica".

13. Dionisotti, Geografia e storia della letteratura italiana, 175.

14. Cotugno, "Piccolomini e Castelvetro traduttori della Poetica"; Cotugno, "Osservazioni linguistiche"; Cotugno, "Le Annotationi di Piccolomini".

15. Sgarbi, "Instatement of the Vernacular".

16. Guthmüller, "Fausto da Longiano e il problema del tradurre", 10-11; Toscanella, Discorsi cinque, 28.

17. Toscanella, Discorsi cinque, 28.

18. Guthmüller writes, correctly, that "around 1550, the fundamental problem of whether it is legitimate to translate or not becomes secondary to the question of how to translate" but, unlike Cotugno, he does not make a distinction between the manner of translation and the technical results of vulgarization. Hence, whereas Cotugno is aware of a distinction between quid iuris and quid facti, Guthmüller appears to confuse the two levels; see Guthmüller, "Fausto da Longiano e il problema del tradurre", 21.

19. Dionisotti, Geografia e storia della letteratura italiana, 167; Guthmüller, "Fausto da Longiano e il problema del tradurre", 13.

20. Guthmüller, "Fausto da Longiano e il problema del tradurre", 21.

21. Marassi, "Bruni e la teoria della traduzione".

22. Some of the assertions by these writers and others may be found in: Guthmüller, "Fausto da Longiano e il problema del tradurre", 21-23; Siekiera, "La Poetica vulgarizzata et sposta per Castelvetro"; Siekiera, "La questione della lingua di Piccolomini"; Siekiera, "Letteratura descrittiva in volgare"; Siekiera, "Riscrivere Aristotele".

23. See McElduff, Roman Theories of Translation, 113-16.

24. Horace, Ad Pisones, 133; Quintilian, Institutio Oratoria, X, 5, 5.

25. Guthmüller, "Fausto da Longiano e il problema del tradurre", 33.

26. Reiff, Interpretatio, imitatio, aemulatio; McLaughlin, Literary Imitation.

27. The greater the fidelity of the translation to the words of the source text, the more the vulgarization will be philological - yet this does not mean that a philological vulgarization will be the best outcome. As we will see, philological meticulousness and closeness to the source text are frequently viewed by the vulgarizers as an obstacle to achieving an effective vulgarization.

28. Cf. Cicero, De oratore, I, 32-33; Cicero, Orator, I, 70; Cicero, De inventione rhetorica, I, 5. See also Sgarbi, The Italian Mind, 23-31.

29. Aristotle, De interpretation 16a, 3-8. In this sense, almost all the theoreticians of vulgarization are Aristotelians.

30. Guthmüller, "Fausto da Longiano e il problema del tradurre", 33.

31. On the new intellectual framework, see Vianello, Il letterato, l'Accademia e il libro.

32. I am using the latest edition by Enrico Garavelli in Castelvetro, Lettere Rime Carmina.

33. Cotugno, "Piccolomini e Castelvetro traduttori della Poetica"; Siekiera, "La Poetica vulgarizzata et sposta per Castelvetro".

34. Romani, "Castelvetro e il problema del tradurre".

35. Castelvetro was writing before the reassessment of Aristotle's Poetics in 1548 with Francesco Robortello's Explicationes.

36. Castelvetro, Poetica d'Aristotele volgarizzata et sposta, 16v; Castelvetro, Lettere Rime Carmina, 134. On poetry as a vehicle of knowledge, see Sgarbi, "Il Socrate Veneziano".

37. Speroni, Opere, vol. 4, 577-78. 
38. Romani, "Castelvetro e il problema del tradurre", 171.

39. Castelvetro, Lettere Rime Carmina, 123.

40. Of the same opinion are Romani, "Castelvetro e il problema del tradurre", 156; Drusi, "Recensione".

41. Castelvetro, Lettere Rime Carmina, 123-24.

42. Castelvetro, Lettere Rime Carmina, 125.

43. Castelvetro, Lettere Rime Carmina, 126; Gellius, Noctes Atticae IX, 1-2.

44. Romani, "Lodovico Castelvetro e il problema del tradurre", 152-179.

45. See Guthmüller, "Literaturgeschichte und Volgare".

46. I quote according Guthmüller's edition in Guthmüller, "Fausto da Longiano e il problema del tradurre. Fausto da Longiano, Dialogo del modo de lo tradurre d'una in altra lingua segondo le regole mostrate da Cicerone", 9-152. Longianus, Dialogo del modo de lo tradurre, 38.

47. I am not referring here to vulgarization because it is not necessarily in the vernacular and it does not necessarily make the content more suitable for the populace.

48. Longianus, Dialogo del modo de lo tradurre, 44.

49. Ibid., 45 .

50. Ibid.

51. Ibid., 156 .

52. Ibid., 46.

53. Ibid., 47.

54. Ibid., 46.

55. Ibid., 49.

56. Ibid., 52.

57. Ibid., 51.

58. Ibid., 54.

59. Ibid., 115.

60. Ibid., 132.

61. Ibid.

62. Ibid., 119.

63. Ibid., 85 .

64. Drusi, "Recensione", 474.

65. Ibid.

66. Longianus, Dialogo del modo de lo tradurre, 135.

67. For the history of this concept, see Rener, Interpretatio.

68. Longianus, Dialogo del modo de lo tradurre, 133.

69. Ibid., 122.

70. Ibid., 151-52.

71. Epistole famigliari di Cicerone.

72. Ibid., Aijv.

73. Ibid.

74. For a description of the manuscript, see Garavelli, "Un frammento di Francesco Robortello".

75. Aristotle, Rhetorica I.2 1358 a.

76. Something similar can be found in Piccolomini, Copiosissima parafrase, 16.

77. Robortello, Biblioteca del Museo Correr, Venezia, Donà dalle Rose 447. misc. XVI-XVII, f. 28 .

78. Ibid.

79. Virgil, Aeneid II, 1.

80. Horace, Odes IV.7.

81. Virgil, Georgic II, 113.

82. See Sgarbi, "Robortello on Popularizing Knowledge".

83. Robortello, Biblioteca del Museo Correr, Venezia, Donà dalle Rose 447, 9r-v.

84. Ibid.

85. Ibid., 13r.

86. Ibid., $15 \mathrm{v}$. 
87. Robortello, Biblioteca Nazionale di Napoli, V D 45, f. 70r.

88. Ibid.

89. See Sgarbi, "Robortello's Rhetoric".

90. The letter was republished with some editorial changes in 1575 in Piccolomini, Annotationi nel libro della Poetica d'Aristotele.

91. Piccolomini, Epistola ai lettori del modo del tradurre, 39. I am quoting here from the critical edition in Cotugno, "Piccolomini e Castelvetro traduttori della Poetica".

92. Piccolomini, Epistola ai lettori del modo del tradurre, 39.

93. Ibid.

94. Ibid., 9.

95. Ibid., 14.

96. Ibid., 17.

97. Ibid. 18.

98. Ibid., 19.

99. Cotugno, "Piccolomini e Castelvetro traduttori della Poetica", 195.

100. Piccolomini, Epistola ai lettori del modo del tradurre, 22.

101. Cotugno, "Piccolomini e Castelvetro traduttori della Poetica", 189.

102. Toscanella, Discorsi cinque, 28.

103. Ibid.

104. Ibid.

105. Ibid.

106. Ibid.

107. Ibid.

108. Ibid., 29.

109. Ibid.

110. Ibid.

111. Toscanella, Prontuario di voci volgari, 144.

112. Ibid.

113. Toscanella, Discorsi cinque, 33.

114. Ibid., 34 .

115. Ibid.

116. Ibid., 30 .

117. Ibid.

118. Ibid.

119. Ibid.

120. Ibid., 29.

121. Ibid., 30 .

122. Ibid., 29.

123. Ibid., 30 .

124. Ibid., 34 .

125. See Garcia, "Parola per parola"; Baldassari, "Il Discorso sopra la traduttione delle scienze".

126. Catena, Delle lettere, 259-60.

127. Catena, Delle lettere, 260.

128. Catena, Discorso sopra la traduttione delle scienze, 2.

129. Ibid., 3 .

130. Ibid., 1-2.

131. Ibid., 2.

132. Ibid., 3 .

133. Ibid., 4.

134. Ibid. As we shall see later, with "moderni" Catena refers to the humanists.

135. Ibid., 38 .

136. Ibid., 61 .

137. Suffice it to recall the criticism leveled by Girolamo Ruscelli at the Trasformationi of Ludovico Dolce: "you and anyone else who translates does not make the poem, rather the poem 
belongs to the poet who recreates, discovers and explains the subject, and ultimately the poem belongs to the one who composes, not the one who translates"; Ruscelli, Tre discorsi, 261.

138. Catena, Discorso sopra la traduttione delle scienze, 61.

139. Ibid., 61-62.

140. Ibid., 63 .

141. Ibid., 83 .

142. Ibid.

143. Ibid., 51.

144. Ibid., 55 .

145. Ibid.

146. Schmitt, Aristotle and the Renaissance.

147. Catena, Discorso sopra la traduttione delle scienze, 56.

148. Ibid., 33.

149. Ibid., 44 .

150. Ibid., 59 .

151. Ibid.

152. Translated by James Hankins in Hankins, Plato in the Renaissance, 44-45, original in Bertalot, "Cincius Romanus und seine Briefe", 210.

153. Sabbadini, "Del tradurre i classici in Italia", 209.

\section{Funding}

This work was supported by the European Research Council [grant no. 335949].

\section{Notes on contributor}

Marco Sgarbi (Mantua, 1982) is associate professor of history of philosophy and vice-provost for communication and development at the Università Ca' Foscari, Venice. He has been the Principal Investigator of the ERC Starting Grant 2013 on "Aristotle in the Italian Vernacular: Rethinking Renaissance and Early-Modern Intellectual History (c. 1400-c. 1650)". He has been a Jean-François Malle-Harvard I Tatti Fellow at Villa I Tatti, The Harvard University Center for Italian Renaissance Studies; Frances A. Yates Short-Term fellow at the Warburg Institute. He is the editor of Philosophical Readings, a four-monthly on-line journal, of the Encyclopedia of Renaissance Philosophy and of the Bloomsbury Studies in the Aristotelian Tradition.

\section{Bibliography}

Aristotle. Opera. Berlin: Reimer, 1831.

Baldassari, Stefano U. "Il Discorso sopra la traduttione delle scienze e d'altre facultà dell'umanista Giorlamo Catena". Per Leggere, 6, no. 11 (2006): 133-147.

Beer Jeanette, M. A., ed. Translation Theory and Practice in the Middle Ages. Kalamazoo: Western Michigan University Press, 1997.

Bertalot, Ludwig. "Cincius Romanus und seine Briefe". Quellen und Forschungen aus Italienischen Archiven und Bibliotheken 21 (1929-1930): 209-255.

Beyers, Rita, Jozef Brams, and Dirk Sacré, ed. Tradition et traduction. Les textes philosophiques et scientifiques grecs au Moyen Age latin. Leuven: Leuven University Press, 1999.

Borsetto, Luciana. L'"Eneida” tradotta. Riscritture poetiche del testo di Virgilio nel XVI secolo. Milan: Unicopli, 1989.

Borsetto, Luciana. Il furto di Prometeo. Imitazione, scrittura, riscrittura nel Rinascimento. Alessandria: Edizioni dell'Orso, 1991.

Castelvetro, Ludovico. Lettere Rime Carmina. Pisa: ETS, 2015. 
Castelvetro, Ludovico. Poetica d'Aristotele volgarizzata et sposta. Vienna: Steinhofer, 1570.

Catena, Girolamo. Discorso sopra la traduttione delle scienze, \& d'altre facultà. Venice: Ziletti, 1581.

Catena, Girolamo. Delle lettere. Rome: Tornieri, 1589.

Contamine, Geneviève, ed. Traductions et traducteurs au Moyen Âge. Paris: CNRS, 1989.

Cicero, Marcus Tullius. De finibus. Oxford: Clarendon Press, 1998.

Cicero, Marcus Tullius. De inventione. De optimo genere oratorum. Topica. Cambridge, MA: Harvard University Press, 1949.

Cicero, Marcus Tullius. De oratore. Cambridge: Cambridge University Press, 2011.

Cicero, Marcus Tullius. Orator. Cambridge, MA: Harvard University Press, 2004.

Cortesi, Mariarosa. "La tecnica del tradurre presso gli Umanisti". In The Classical Tradition in the Middle Ages and the Renaissance, edited by Claudio Leonardo and Birger Munk Olsen, 143-168. Spoleto: CISAM, 1995.

Cotugno, Alessio. "Le Annotationi di Piccolomini e la Poetica di Castelvetro a confronto: tecnica argomentativa, vocabolario critico, dispositivi esegetici”. In Renaissance Conflict and Rivalries Research Colloquium, edited by David A. Lines, 161-206. Göttingen: Bonn University Press, 2015.

Cotugno, Alessio. "Osservazioni linguistiche sull'Instrumento della filosofia di Alessandro Piccolomini. Testualità, lessico, procedimenti espositivi”. In Aristotele fatto volgare. Tradizione aristotelica e cultura volgare nel Rinascimento, edited by David A. Lines and Eugenio Refini, 99-148. Pisa: ETS, 2014.

Cotugno, Alessio. "Piccolomini e Castelvetro traduttori della Poetica (con un contributo sulle modalità dell'esegesi aristotelica nel Cinquecento)". Studi di lessicografia italiana 23 (2006): 113-219.

De Campos, Haroldo. "De la traduction comme création et comme critique". Change 14 (1973): 71-84.

Dionisotti, Carlo. Geografia e storia della letteratura italiana. Turin. Einaudi, 1999.

Drusi, Riccardo. "Recensione a Bodo Guthmüller, Faustus Longianus e il problema del tradurre, «Quaderni Veneti», 12, 1990, pp. 9-152". Lettere italiane 45 (1993): 468-475.

Epistole famigliari di Cicerone. Venice: Manuzio, 1545.

Folena, Gianfranco. Volgarizzare e tradurre. Turin: Einaudi, 1991.

Garavelli, Enrico. "Un frammento di Francesco Robortello 'del traslatare d'una lingua in l'altra"'. In Studi italianistica nordica, edited by Marco Gargiulo, Margareth Hagen, and Stefano Rosatti, 287-305. Rome: Aracne, 2014.

Garcia, Teresa Gil. "Parola per parola (ovvero Discorso sulla traduzione di Girolamo Catena)". In Prospettive nello studio del lessico italiano, edited by Emanuela Cresti, 621-627. Florence: Florence University Press, 2006.

Guido da Pisa. Fiore d'Italia. Bologna: Turchi, 1824.

Guthmüller, Bodo. "Antico-moderno, latino-volgare. Zum literarischen Traditionsbewußtsein im Cinquecento". In Die Präsenz der Antike im Übergang vom Mittelalter zur Frühen Neuzeit, edited by Ludger Grenzmann, Fidel Rädle, and Martin Staehelin, 231-46. Göttingen: Vandenhoeck \& Ruprecht, 2004.

Guthmüller, Bodo. "Fausto da Longiano e il problema del tradurre. Fausto da Longiano, Dialogo del modo de lo tradurre d'una in altra lingua segondo le regole mostrate da Cicerone". Quaderni Veneti 12 (1990): 9-152.

Guthmüller, Bodo. "Letteratura nazionale e traduzione dei classici nel Cinquecento". Lettere Italiane 45 (1993): 501-518.

Guthmüller, Bodo. "Literaturgeschichte und Volgare in der ersten Hälfte des Cinquecento". In Deutsche Forschungsgemeinschaft: Humanismus und Historiographie, edited by August Buck, 105-123. Weinheim: Acta humaniora, 1991.

Guthmüller, Bodo. Ovidio Metamorphoseos vulgare. Formen und Funktionen der volkssprachlichen Wiedergabe Klassicher Dictung in der italienischen Renaissance. Boppard am Rhein: Bold, 1981.

Guthmüller, Bodo. "Die volgarizzamenti". In Grundriß der romanischen Literaturen des Mittelalters, Bd. 10: Die italienische Literatur im Zeitalter Dantes und am Übergang vom 
Mittelalter zur Renaissance, edited by August Buck, Dorothea Kullmann, Frank Seemann, Hans Ulrich Gumbrecht, and Ulrich Mölk, 201-254 and 333-348. Heidelberg: Winter, 1989.

Hamesse, Jacqueline, ed. Les traducteurs au travail. Leurs manuscrits et leur méthodes. Turnhout: Brepols, 2001.

Hankins, James. Plato in the Renaissance. Leiden: Brill, 1990.

Hewson, Lance. "The Vexed Question of Creativity in Translation". Palimpsestes, Hors série (2006): 54-63.

Horace Flaccus, Quintus. Opera. Oxford: Clarendon Press, 1963.

Marassi, Massimo. "Leonardo Bruni e la teoria della traduzione". Studi umanistici piceni 29 (2009): 123-141.

McElduff, Siobhán. Roman Theories of Translation. Surpassing the Source. London: Routledge, 2013.

McLaughlin, Martin L. Literary Imitation in the Italian Renaissance: The Theory and Practice of Literary Imitation in Italy from Dante to Bembo. Oxford: Clarendon Press, 1995.

Morlino, Luca. "Volgarizzare e trasporre. Una postilla al lessico della traduzione". Critica del testo, 17 (2014): 143-157.

Norton, Glyn P. "Humanist Foundations of Translation Theory (1400-1450): A Study in the Dynamics of Word". Canadian Review of Comparative Literature 8, no. 2 (1981): 173-203.

Norton, Glyn P. The Ideology and Language of Translation in Renaissance France and their Humanist Antecedents. Geneva: Droz, 1984.

Norton, Glyn P. "Translation Theory in Renaissance France: Etienne Dolet and the Rhetorical Tradition". Renaissance and Reformation 10, no. 1 (1974): 1-13.

Paris, Jean. "Translation and Creation". In The Craft and Context of Translation, edited by William Arrowsmith and Roger Shattuck, 57-67. Austin: University of Texas Press, 1961.

Piccolomini, Alessandro. Annotationi di M. Alessandro Piccolomini, nel libro della Poetica d'Aristotele; con la traduttione del medesimo libro, in lingua volgare. Venice: Varisco, 1575.

Piccolomini, Alessandro. Copiosissima parafrase nel primo libro della Retorica d'Aristotele. Venice: Varisco, 1565.

Porro, Antonietta. "Volgarizzamenti e volgarizzatori di drammi euripidei a Firenze nel Cinquecento". Aevum 55 (1981): 481-508

Quintilian, Marcus Fabius, Institutionis oratoriae. Oxford: Clarendon, 1970.

Reiff, Arno. Interpretatio, imitatio, aemulatio. Begriff und Vorstellung literarischer Abhängigkeit bei den Römern. Würzburg: Triltsch, 1959.

Rener, Frederick M. Interpretatio: Language and Translation from Cicero to Tytler. Amsterdam: Rodopi, 1989.

Robortello, Francesco. Biblioteca del Museo Correr, Venezia, Donà dalle Rose 447. Francesco Robortello, Francesco. Biblioteca Nazionale di Napoli, V D 45.

Romani, Werther. "Lodovico Castelvetro e il problema del tradurre". Lettere italiane 2 (1966): 152-179.

Ruscelli, Girolamo. Tre discorsi. Venice: Pietrasante, 1553.

Sabbadini, Remigio. "Del tradurre i classici in Italia”. Atene e Roma 3 (1900): 202-217.

Schmitt, Charles B. Aristotle and the Renaissance. Cambridge, MA: Harvard University Press, 1983.

Segre, Cesare. "I volgarizzamenti del Due e Trecento". In Lingua, stile e società, 49-78. Milan: Feltrinelli, 1963.

Sgarbi, Marco. "Aristotle and the People: Vernacular Philosophy in Renaissance Italy". Renaissance \& Reformation 39, no. 3 (2016): 59-109.

Sgarbi, Marco. "Francesco Robortello on Popularizing Knowledge". In Vernacular Aristotelianism in Italy from the Fourteenth to the Seventeenth Century, edited by Luca Bianchi, Simon Gilson, and Jill Kraye, 75-92. London: The Warburg Institute, 2016.

Sgarbi, Marco. "Francesco Robortello's Rhetoric: On the Orator and His Arguments". Rhetorica: A Journal of the History of Rhetoric 34, no. 3 (2016): 243-267.

Sgarbi, Marco. "The Instatement of the Vernacular as Language of Culture: A New Aristotelian Paradigm in Sixteenth-Century Italy". Intersezioni 36 (2016): 319-343. 
Sgarbi, Marco. The Italian Mind: Vernacular Logic in Renaissance Italy (1540-1551). Leiden: Brill, 2014.

Sgarbi, Marco. "Il Socrate Veneziano, Trifon Gabriele: Tre scritti filosofici”. Historia philosophica 13 (2015): 11-31.

Siekiera, Anna Maria. "Letteratura descrittiva in volgare. Forme e modelli delle Antichità di Roma". In Saggi di letteratura architettonica da Vitruvio a Winckelmann, edited by Howard Burns, Francesco Paolo Di Teodoro, and Giorgio Bacci, 321-337. Florence, Olschki, 2010.

Siekiera, Anna Maria. "La Poetica vulgarizzata et sposta per Lodovico Castelvetro" e le traduzioni cinquecentesche del trattato di Aristotele". In Ludovico Castelvetro. Letterati e grammatici nella crisi religiosa del Cinquecento, edited by Massimo Firpo and Guido Mongini, 25-45. Florence: Olschki, 2008.

Siekiera, Anna Maria. "La questione della lingua di Alessandro Piccolomini". In Alessandro Piccolomini (1508-1579). Un siennois à la croisée des genres et des savoirs, edited by MarieFrançoise Piéjus, Michel Plaisance, and Matteo Residori, 217-233. Paris: Centre Interuniversitaire de Recherche sur la Renaissance Italienne-Université Sorbonne Nouvelle Paris 3, 2011.

Siekiera, Anna Maria. "Riscrivere Aristotele: la formazione della prosa scientifica in italiano". In Aristotele fatto volgare. Tradizione aristotelica e cultura volgare nel Rinascimento, edited by David A. Lines and Eugenio Refini, 149-167. Pisa: ETS, 2014.

Speroni, Sperone. Opere. 5 vols. Venice: Occhi, 1740.

Steiner, George. After Babel: Aspects of Language and Translation. Oxford: Oxford University Press, 1975.

Tesi, Riccardo. Aristotele in Italiano. I grecismi nelle traduzioni rinascimentali della Poetica. Florence: Accademia della Crusca, 1997.

Toscanella, Orazio. Discorsi cinque. Venice: De Franceschi, 1575.

Toscanella, Orazio. Prontuario di voci volgari, et latine, copiosissimo per imparare con somma brevità, \& facilità a scrivere latino con la citatione succinta delle voci, \& locutioni d'Autori famosi, da quali sono tratte. Venice: Valgrisi, 1565.

Trovato, Paolo. Storia della lingua italiana. Il primo Cinquecento. Bologna: il Mulino, 1994.

Vianello, Valerio. Il letterato, l'Accademia e il libro. Contributi sulla cultura veneta del Cinquecento. Padua: Antenore, 1988.

Virgil Maro, Publius. Opera. Oxford: Clarendon, 1969.

Worth-Stylianou, Valerie. "Translatio and Translation in the Renaissance: From Italy to France". In The Cambridge History of Literary Criticism, Vol. 3, edited by Glyn P. Norton, 127-135. Cambridge: Cambridge University Press, 1999.

Worth, Virginia. Practising Translation in Renaissance France: The Example of Etienne Dolet. Oxford: Clarendon Press, 1988. 